\title{
THE CONSTITUTIONAL POWER AND RELATION OF THE STATE AND FEDERAL COURTS
}

One of the earliest and loftiest conceptions of God is as the Great Judge Eternal of the Universe; and so, the most exalted function with which a man can be entrusted is the administration of justice to his fellow beings. Hence, it has been said by a great philosopher that, in the performance of their official duties, Judges "should imitate God, in whose seat they sit." 1

It is doubtless because of these high and exacting requirements that, as was said in connection with Chief Justice Marshall, "the world has produced fewer instances of truly great Judges than it has of great men in almost any other department of life." 2

The Judicial Office is as old as organized society. Originally, it was filled, in person, by the head of the communitywhether Priest, Patriarch or King-who proudly styled himself the "Fountain of Justice." Later on, as states became more populous and society more complex, the administration of justice had to be entrusted to personal representatives of the sovereign, taken from the body of the people; and thus was first formed the Judiciary, an institution, which, in one form or another, is, and for time out of mind has been, common to all governments.

The Judiciary, however, will be found to be very different in different ages and in different countries, because, the freedom, the virtue and the happiness of a People may be adequately measured by the independence, integrity and prestige of its Judiciary. Edmund Burke said: "It is the public justice that holds the Community together ;" 3 and certain it is that a truly great Judge can exist only in an age of political liberty and public morality, "in which he is the representative of the abstract justice of the people in the administration of the law, ancl is rewarded for the highest achievements of duty, by proportionate admiration and reverence." 4

1 Lord Bacon-Essay LVII of Judicature.

2 Horace Binney-Eulogy on John Marshall, 1835.

${ }^{3}$ Speech on the Plan for Economical Reform, Feb. II, 1780.

1 Horace Binney-Eulogy on John Marshall, 1835. 
These observations are true of the Judiciary all over the world, but in the United States, the Judiciary occupies a position which, so far as any European Country is concerned, is wholly unique.

Prior to the advent of what I may call the "American theory" of the Judiciary, that arm of the government was wholly subject, and subordinate to the Legislative or Executive branch, or to both; and was a mere creature of one or both of those departments, according as one or the other, or both of them, formed the dominant power in the State.

The independence of the Judiciary, as understood and practiced in America, did not necessarily grow, as some suppose, out of the separation of governmental powers into Legislative, Judicial and Executive. This classification exists necessarily, in the very nature of those powers, and the mere fact that these different functions of government are performed by separate departments, would not necessitate all of those departments being independent of each other; on the contrary, in England (whose government Montesquieu cites as an ideal example of the separation of these three departments) the legislative department-Parliament-is supreme in authority over both the others.

In America was developed the theory that the ultimate sovereignty in human society exists in the organized body of the People as a whole, and in that body, alone, exists that divine right to rule which some Monarchs still arrogate to themselves.

Now, it is, of course, physically impossible for all the powers of Sovereignty, in a large State or Nation, to be personally and directly exercised by the Sovereign itself, whether that Sovereign be one man-the Monarch-or ten million men organized as one body-the Nation itself. Hence, just as an absolute monarch (in order to enable him to exercise the powers and perform the duties of Sovereignty which he could not do in person) would estabTish a government consisting of a Board of Councilors to consider and make laws, a Board of Judges to construe and administer them, and a Commander of his military forces to execute the laws and defend the country from foreign foes, and just as these persons would not act in their own names, but in the name, and as the servants and representatives of their Sovereign Monarch; so, even when that Sovereign is not a single Monarch, but the organized bodly of the 
whole People, acting as a Nation, yet it acts in the same way as would a single Monarch; that is to say-being unable to personally and directly exercise all the powers of sovereignty, and, acting and speaking through its written constitutions-through which, alone, the Sovereign People can speak and act-it forms a government, just like the single Monarch would do, composed of a Legislative branch, to consider and make laws, a Judicial branch to construe and arlminister them, and an Executive branch to execute the laws and defend the country from its foes.

Neither one of these branches is sovereign any more than was Field Marshall Oyama, the Sovereign of Japan, because he commanded all of the Mikado's forces. Each branch of the government is but the creature, representative, and servant of the Sovereign which created it, and which, in Russia would be the Czar, in Japan, the Mikado, and in the United States, the American People.

While these governmental departments are all servants of one master, that is to say, the real Sovereign, yet, within the scope of their respective spheres, it is important that they be independent of each other, lest one, obtaining mastery over its fellow servants, should succeed in wresting the actual Sovereignty from their common master. To avoid the possibility of this, the Sovereign People, whose servants the governmental departments are, have, in the constitution which created the government, prescribed certain checks and balances so as to preserve the independence of these departments and to correct an abuse of power by either of them, without necessitating a resort to the Sovereign itself, that is, to the People as a Nation in their primary capacity.

Now, this, in brief, is the American theory of government, and one of its consequences is to place the Judiciary, as a coordinate department of our government, on a full equality with each of the other two departments, in the matter of their mutual independence of each other and of the direct accountability of each to their common master, the organized People of the Nation, the true and only Sovereign of this country.

A result of this mutual independence and common accountability of the Legislative, Judicial and Executive Departments of the government, has been to impose upon the American Judiciary a function which had no prototype in the world, and, to this day, has no counterpart in Europe; I refer to the func- 
tion of passing upon the constitutionality and therefore, the validity, of statutes enacted by the Legislative branch, a function the most delicate and important with which the Judiciary of any country was ever entrusted.

The history of the Supreme Court of the United States affords the best, as well as the most notable, example of the practical application and successful operation of this American theory of the Judiciary, although that theory is of universal application in the governments of the several States composing the Union. "I take it as the highest encomium on this country," said Patrick Henry, "that the acts of the Legislature, if unconstitutional, are liable to be opposed by the Judiciary." "

The Supreme Court of the United States being by far the most prominent court in this country-and for that matter, the most notable tribunal in the world-it is not surprising that foreigners should have supposed that this American idea of the right-no, I will say, bounden duty-of a court to refuse recognition to a statute on the ground of its unconstitutionalityhad its origin with the creation of the Supreme Court by the Federal Convention of 1787. Accordingly, we find so learned and accurate a writer as Sir Henry Maine referring to that court as "a virtually unique creation of the founders of the Constitution." " Even a notable American historian calls the Supreme Court "the most original work accomplished by the founders of the Constitution," " and says that that court had "no prototype in history"- the peculiar characteristic referred to by both of these writers being the right of the court to refuse recognition to unconstitutional statutes.

But, as has been observed by others, this is not strictly correct. In fact, it may be said that great, valuable and enduring institutions are never the work of invention but are always the result of evolution; and this was true of the Supreme Court of the U'nited States.

It is true that the right and duty of the courts to refuse recognition to an unconstitutional law would seem to follow as a necessary consequence of the adoption of a written constitution; and yet it may be doubted if that consequence would have followed in America, but for the peculiar situation and exper-

3 Elliot's Debates, p. 325.

6 Popular Government, p. 217.

7 Taylor's Jur. \& Pro. of Supreme Court, p. I, et seq. 
ience of the American people which gradually educated them up to the point; because, in Switzerland, where they have a written constitution also, the Legislative branch is expressly made the sole judge of the constitutionality of its enactments and the Judiciary is bound thereby.

In the American colonies, the legislatures never did have, or claim, the absolute or unlimited power of legislation. These colonies, for the most part, were mere business corporations, gotten up for the purpose of trade and created by charters of incorporation, which provided for their organization and government. These old charters first suggested the idea of our written constitutions, which, in 1776 (though previously suggested once or twice by philosophers), formed an entirely new departure in actual governmental organization. Of course the Legislative Assembly of a colony had no powers whatever, except such as were conferred upon it by the charter of the colony, or by some special enabling Act of Parliament, and so, at an early day, the courts were called upon, from time to time, to refuse recognition to the ultra vires enactments of Colonial Assemblies, as in the case of Winthrop $v$. Lechemere ${ }^{8}$ in which the English Court held a statute passed by the Colonial Assembly of Connecticut to be void as contrary to the charter of that Colony and to English law: ${ }^{9}$

Accordingly, when the Colonies declared their independence, and began to establish governments of their own, not only were they (from their previous experience with the British Parliament and its claims of omnipotence) particularly fearful of usurpation of authority by the Legislative branch, but they were thoroughly accustomed to seeing that branch, as it had existed in the colonies, subjected to the check of judicial inquiry into the constitutionality of its acts. The early State courts therefore, did not fail to apply this check to the new State legislatures, just as the old Judiciary had done to the Colonial assemblies.

As far back as I780, Chief Justice Brearly of the New Jersey Supreme Court, is said to have given it as the opinion of himself and associates that the judiciary had the right to pass upon the constitutionality of statutes. ${ }^{10}$

\footnotetext{
${ }^{8}$ Willoughby's Sup. Ct. of the U. S., p. 2.

${ }^{2}$ Bryce's American Commonwealth, p. 234-4.

${ }^{10}$ Holmes v. Walton (unreported) cited in State v. Parkhurst, 9 N. J. Law Rep. Appendix p. 444; Sparks' Life of Governeur Morris, Vol. 3, p. 438; Cooley's Constitutional Limitations, Chap. III, p. 55, note I.
} 
In 1782 , in the celebrated case of Commonwealth $v$. Caton, before the Virginia Court of Appeals, the distinguished Edmund Randolph, then Attorney General of that State, contended that the court had no choice but to apply a duly enacted statute, whether it be unconstitutional or not; but, to this contention, stout-hearted old Chancellor Wythe replied, with warmth, as follows :

"If the whole Legislature (an act to be deprecated) should attempt to overleap the bounds prescribed to them by the people, $\mathrm{I}$, in administering the public justice of the Country, will meet the United Powers in my seat on this tribunal, and, pointing to the Constitution, will say to them 'Here is the limit of your authority and hither shall you go but no further'." 11

Accordingly, that court held that it did have the power to declare any law void if unconstitutional. To the official report of this case in the Virginia Reports, is appended the following note by Daniel Call, the distinguished old reporter:

"It is said, that this was the first case in the United States, where the question relative to the mullity of an unconstitutional law was ever discussed before a judicial tribunal; and the firmness of the judges (particularly of Mr. Wythe), was highly honorable to them; and will always be applauded, as having, incidentally, fixed a precedent whereon a general practice, which the people of this country think essential to their rights and liberty, has been established." 12

The matter, however, of declaring a statute unconstitutional gave the judges sufficient concern to cause them in a later case to address a remonstrance to the General Assembly of Virginia, in which they said they had "found it unavoidable to consider * * * whether the principles (expressed in the Legislative Acts) of this case do not violate those of the Constitution or form of government which the people in I776*** established as the foundation of that government which they judged necessary for the preservation of their persons and their property, and, if such violations were apparent, whether they (the Judges) had the power, and it was their duty, to declare that the act must yield to the Constitution? On this view of the subject (said they), the following alternatives presented themselves to the Court: either to decide those questions or to resign their offices. They judged that a resignation would subject them to the reproach of deserting their stations, and on that ground, found themselves obliged to decide, and in that decision to declare, that

${ }^{11}$ Commonwealth v. Caton, 4 Call. (Va.) p. 8.

${ }^{12}$ Commonwealth v. Caton, 4 Call. (Va.) p. 2 I. 
the Constitution and the act are in opposition and cannot exist together, and that the former must control the latter." ${ }^{13}$

In I786, a defence, on the ground of the alleged unconstitutionality of a law, was made before the Rhode Island Court in Trevitt $v$. Weeden, ${ }^{14}$ though I believe the case was decided on some other point.

In 1787 , the Supreme Court of North Carolina in Bay'ard $v$. Singleton, ${ }^{15}$ declared a Statute unconstitutional and void. The court, in that case, discussing its power to declare an act of the Legislature unconstitutional, said, among other things:

"Another mode was proposed for putting the matter in controversy on a more constitutional footing for a decision than that of the motion under the aforesaid act. The court then, after every reasonable endeavor had been used in vain for avoiding a disagreeable difference between the Legislature and the judicial powers of the State, at length, with much apparent reluctance, but with great deliberation and firmness, gave their opinion separately, but unanimously for overruling the aforementioned motion for the dismission of the said suits, in the course of which the judges observed that the obligation of their oaths and the duty of their office required them in that situation to give their opinion on that important and momentous subject, and that, notwithstanding the great reluctance they might feel against involving themselves in a dispute with the Legislature of the State, yet no object of concern or respect could come in competition or authorize them to dispense with the duty they owed the public, in consequence of the trust they were invested with under the solemnity of their oaths; that they, therefore, were bound to declare that they considered that whatever disabilities the persons under whom the plaintiffs were said to derive their title might justly have incurred against their maintaining or prosecuting any suits in the courts of this State, yet that such disabilities in their nature were merely personal, and not by any means capable of being transferred to the present plaintiffs, either by descent or purchase, and that these plaintiffs being citizens of one of the United States, or citizens of this State, by the confederation of all the States which is to be taken as a part of the law of the land, unrepealable by any act of the General Assembly; that by the Constitution every citizen had undoubtedly a right to a decision of his property by a trial by jury, for that if the Legislature could take away this right, and require him to stand condemned in his property without a

${ }^{13}$ The Case of the Judges, 4 Call. (Va.) 135. See also The Advocate. (a Minneapolis Law Journal) for May, 1889.

14 Storey on The Constitution, Vol. I, p. 226, note I, and p. 369 , note I; Cooley's Constitutional Limitations, Chap. VII, p. 229, note I.

${ }^{15}$ I Martin (N. C.) p. 42. 
trial, it might with as much authority require his life to be taken away without a trial by jury, and that he should stand condemned to die without the formality of any trial at all; that, if the members of the General Assembly could do this, they might with equal authority not only render themselves the legislators of the State for life, without any further election of the people, from thence transmit the dignity and authority of legislation down to their heirs male forever; but that it was clear that no acts they could pass could by any means repeal or alter the Constitution, because, if they could do this, they would at the same instant of time destroy their own existence as a Legislature, and dissolve the government thereby established. Consequently, the Constitution (which the judicial power was bound to take notice of as much as of any other law whatever), standing in full force as the fundamental law of the land, notwithstanding the act on which the present motion was grouncled, the same act must, of course, in that instance, stand as abrogated and without any effect." 16

In a letter, dated 1788, from $\mathrm{Mr}$. Cutting to Mr. Jefferson, it is stated that several years before that, the Supreme Court of Massachusetts had declared a Statute unconstitutional and void. ${ }^{17}$

Thus, it will be seen that the idea of clothing the Judiciary with the power of reviewing the constitutionality of legislative acts, did not originate along with the Supreme Court of the United States, in the Convention of 1787 , but was an idea which the American people, were, even at that time, already not only familiar with but definitely attached to. See the very interesting case of Borman v. Middleton, I Bay 252, in which the Supreme Court of South Carolina, in I792, set aside a statute as being in violation of Magna Charta and Common Right.

The first instance in which this power seems to have been exercised by a Federal Court, was in Hayburn's case in I79I, in which the Judges of a United States Circuit Court refused to exercise functions imposed upon them by Act of Congress because the Act was inconsistent with the Constitution. ${ }^{18}$

In 1803 , the question came, for the first time, before the Supreme Court of the United States, in the celebrated case of Marbury v. Madison, in which Chief Justice Marshall decided against the constitutionality of a statute which enlarged the

${ }^{16}$ Bayard v. Singleton, I Martin (N. C.) 42.

17 Bancroft's History of the Constitution, Vol. II, p. 472-3.

${ }^{18}$ Hayburn's Case, 2 Dallas, 409. See also Van Horne v. Dorrance (1795), 2 Dallas, 304, especially Judge Patterson's opinion on p. 309, et seq. 
jurisdiction of that court at the expense of the Executive Department, and rendered a decision of such convincing and irrefutable logic, that the question was settled forever. In his opinion he said:

"The powers of the Legislature are defined and limited. To what purpose is that limitation committed to writing, if these limits may, at any time, be passed, by those intended to be restrained? * * * It is a proposition too plain to be contested that either the Constitution controls any legislative act repugnant to it or that the Legislature may alter the Constitution by an ordinary act. Between these two alternatives there is no middle ground. The Constitution is either a superior paramount law * * * or it is on a level with ordinary legislative acts *** If the former part of the alternative be true, then a legislative act contrary to the Constitution is not law; if the latter part be true, then written constitutions are absurd attempts on the part of the people to limit a power, in its own nature illimitable."19

In 1816, in he great case of McCulloch $v$. Maryland, Chief Justice Marshall, while sustaining a statute which had been attacked on the ground that it was an undue assumption of power by Congress, again expressed himself about the exercise of this novel function of passing on the constitutionality of a statute, saying:

"Let the end be legitimate, let it be within the scope of the Constitution, and all means which are appropriate, which are plainly adapted to that end, which are not prohibited but consist with the letter and spirit of the Constitution, are constitutional. *** Should Congress in the execintion of its powers, adopt measures which are prohibited by the Constitutions or should Congress, under pretext of executing its powers, pass laws for the accomplishment of objects not entrusted to the government, it would become the painful duty of this tribunal, should a case requiring such decision come before it, to say that such an act was not the law of the land. But where the law is not prohibited and is really calculated to effect any of the objects entrusted to the government, to undertake to enquire here into the degree of its necessity would be to pass the line which circumscribes the judicial department and to tread on legislative ground. This court disclaims all pretensions to such a power." ${ }^{20}$

When we consider these interpretations of this, the greatest of judicial powers, and the impartial, disinterested and moderate exercise of that power which led the Court to first overthrow

19 Marbury v. Madison, I Cranch, I76-7.

${ }^{20} \mathrm{McC}$ ulloch v. Maryland, 4 Wheaton, p. $42 \mathrm{I}$. 
a statute designed to extend its own preogatives, and then to sustain a statute alleged to be an undue assumption of power by a co-ordinate branch of government, we may join with William Pinckney in saying that we see, in these omens, "a pledge of immortality for the Union."

The first tribunal, in the nature of a Federal Court, that ever existed in this country, was the old "Court of Appeals in Cases of Capture," ${ }^{21}$ created by the Continental Congress in I779, ten years before the Supreme Court of the United States came into being. ${ }^{22}$ This court, which had cognizance only of prize cases growing out of captures of hostile ships, was composed of three Judges and was required to proceed in accordance with International Law, and the respective States were called upon to enforce its decrees.

Two years latcr, in $178 \mathrm{I}$, by the old Articles of Confederation, a second step was taken towards the establishment of a Federal Judiciary, by giving Congress power to decide "all disputes and differences now subsisting, or that hereafter may arise, between two or more States concerning boundary, jurisdiction or other cause whatsoever." ${ }^{23}$ It was provided, however, that this power was to be exercised through commissioners or judges, to be selected by Congress from each of the States. Upon the establishment of the Supreme Court of the United States, this power among others was conferred upon it, and, as Chief Justice Taney observed in the case of the State of Florida against the State of Georgia (which was a suit brought in the Supreme Court to settle the boundary line between those States): "A suit in a court of justice between such parties and upon such a question is without example in the jurisprudence of any other country." 24

Something like one hundred and twenty cases were, first and last, decided by the two original tribunals just referred to.

Finally, in 1787 , was created by the New Constitution, the great Supreme Court of the United States, the origo et fons of the real Federal Judiciary, and the most august, powerful, and venerated judicial tribunal ever known in the world.

Judge Story says that "the lack of a separate Judiciary had been one of the vital defects of the Confederation." ${ }^{25}$ Accord-

21 I3I U. S. Appendix, p. XIX.

22 Taylor's Jur. \& Pro. Sup. Ct. pp. 7-8.

23 Taylor's Jur. \& Pro. Sup. Ct. pp. 8-9; I3r U. S. Appendix p. XLIX.

24 Florida v. Georgia, 17 How. 494.

${ }^{25}$ Story on Constitution, Sec. 1574. 
ingly, each of the four drafts of the proposed Constitution, which, by Randolph, Pinckney, Paterson and Hamilton, respectively, were submitted to the Convention of 1787 , contained provisions for a regular Federal Judiciary system.

At one time, it was proposed to authorize Congress to negative unconstitutional acts passed by state legislatures; because, as earnestly pointed out by $\mathrm{Mr}$. Madison, control over state legislation violative of the Federal Constitution, is absolutely essential to the preservation of the Nation. But, as was pointed out by Rodger Sherman, Congress is not the proper body to exercise this control; "for," said he, "it is a wrong principle to assume that a State Statute violative of the Federal Constitution could be valid or operative for any purpose, unless or until negatived or repealed by a subsequent Act of Congress." ${ }^{26}$

Thus, it fell naturally and properly to the Judiciary to exercise this control by refusing recognition to any State statutejust as it must, to any act of Congress-which is in violation of the Federal Constitution.

The first case in which the Supreme Court of the United States decided a State statute to be unconstitutional, was United States v. Peters, ${ }^{27}$ from Pennsylvania in 1809.

When the Judiciary Article of the Federal Constitution came from the Committee on Detail of the Convention of 1787 , it gave to the Supreme Court jurisdiction in "all cases arising under the laws passed by the Legislature of the United States;"28 but the Convention changed this to read: All cases, in law and equity, arising under this Constitution, the laws of the United States and Treaties made, or which shall be made under their authority." 28

While the Constitution was pending before the people for its adoption, it was, in some instances, urged against its adoption that this clause was too vague and general. ${ }^{30}$ To this objection, Mr. Deane, in the North Carolina Ratifying Convention, made reply as follows:

"For my part, I know but two ways in which the laws can be executed by any government $* * *$ The first mode is by coercion by military force, and the second is coercion through

\footnotetext{
${ }^{20} 5$ Elliot's Debates, pp. 321-2.

${ }^{27} 5$ Cranch, II5.

${ }^{28}$ I Elliot's Debates, p. 229.

${ }^{29} 5$ Elliot's Debates, pp. $483,563$.

${ }^{30}{ }_{4}$ Elliot's Debates, p. 136.
} 
the Judiciary. With respect to coercion by force, I shall suppose that it is so supremely repugnant to the principles of justice and the feelings of a free people, that no man will support it. It must, in the end, terminate in the destruction of the liberties of the people. I take it therefore that there is no rational way of enforcing the laws but by the instrumentality of the Judiciary *** Without a Judiciary, the injunctions of the Constitution may be disobeyed and the positive regulations neglected and contravened." 31

The provision of the Federal Constitution for the establishment of a complete Federal Judiciary, was given effect by the great Judiciary Act, drawn by Oliver Ellsworth and passed by Congress in 1789. This Act, by which the flesh was put upon the skeleton created by the Constitution, is justly regarded as in the forefront of excellence in statutory draftsmanship. When first organized, the Supreme Court of the United States consisted of a Chief Justice and five Associate Justices; but the number of Associate Justices is now eight.

The following, in the order named, have been the Chief Justices of the Supreme Court of the United States:

John Jay (a great lawyer and statesman, of whom Mr. Webster beautifully said: "When the spotless ermine of the judicial robe fell upon John Jay, it touched nothing less spotless than itself") ; John Rutledge (who was appointed, but not confirmed); William Cushing (who resigned within about a week after confirmation); Oliver Ellsworth (draftsman of the Judiciary Act of I789); John Marshall (the greatest of all judges); Roger B. Taney, Salmon P. Chase; Morrison R. Waite, and Melville W. Fuller.

At first, the Court had very little business; but, as the country grew and prospered, the business of that great tribunal increased to such an extent that nine intermediate Courts of Appeal have been organized to relieve it of the less important matters.

During their respective terms as Chief Justice, and without resigning that office, Jay served as Minister to England, and Ellsworth as Minister to France.

At its first session, the Supreme Court of the United States had not a single case upon its docket; from I790 to 1800 there were only six cases decided by that Court involving Constitutional questions; and when Chief Justice Marshall came upon the bench he found only ten cases awaiting decision.

${ }^{81}{ }_{4}$ Elliot's Debates, p. 155. 
With Marshall, however, the Supreme Court, though twelve years old, may be said to have really begun its life. He was Chief Justice thirty-four years.

It may be said that the Constitution formed the skeleton of this Nation, that Congress put on the flesh, and that the Supreme Court shaped the figure and regulated the growth. In this great work, Marshall has probably done more than all the other members of that court from the beginning to the present time; and in the opinion of many, this country owes more to him than to any other single man, with the possible exception of Washington himself.

It is difficult for us to realize the magnitude of the task which, upon his appointment as Chief Justice, he undertook, so different are present conditions from those which at that time existed. The Federal Government was then practically beginning its existence, and almost nothing had been done in developing our constitutional law. The scanty decisions of the Supreme Court, up to that time, were nearly all contained in a single volume of the official reports, and of those decisions, few dealt with constitutional questions. The people, as Edmund Randolph expressed it, were still "in the infancy of the science of constitutions." 32 And so, with no precedents to guide him, and with little or no aid to be derived from books, he may be said to have created our system of constitutional law, laying its foundations broad and deep. Other judges have won renown in administering technical or general principles of law, or in this or that department of jurisprudence as applied to controversies between individuals; but, in the department of constitutional law-law as applied to the science and institutions of government-Marshall stands unrivalled and supreme. His judgments, so fraught with deepest consequences to the American people, are justly ranked amongst the highest efforts of the human mind, and are distinguished as well for their simplicity and lucidity of style as for their irresistible logic and profound wisdom.

$\mathrm{He}$ believed in the intelligence, conservatism and patriotism of the American people, and did not hesitate to interpret the Constitution as creating "a government of the People, by the People and for the People," and not merely as a continuing league of States such as was the old Confederation. He main-

${ }^{32} 5$ Elliot's Debates, p. 126. 
tained that, while the national government is one of enumerated powers, the Constitution should be construed not strictly, but reasonably, so as to give due effect to the words employed.

And so, by his interpretation of the Constitution, he imparted to it life and vigor-finding it mere paper, he left it a Chart for the government of a Nation.

But, while maintaining the supremacy of the Constitution, as reasonably interpreted, he not less clearly recognized the rights of the states. "In America," he said, "the powers of sovereignty are divided between the government of the Union and those of the states. They are each sovereign with respect to the objects committed to it, and neither sovereign with respect to the objects committed to the other." ${ }^{33}$ He perceived that an aggregation of states, each controlling its domestic concerns under a common head, invested with limited powers for national purposes, is the only system adapted to the government of a vast territory like ours, and that, therefore, the states and the United States are component parts of one great whole, the one being as needful as the other; or, as an eminent writer happily expresses it, "the Union without self-existent States is as a harp without strings; the States without union are as chords that are unstrung"-a principle recognized by the Supreme Court in Texas $v$. White, ${ }^{34}$ decided in 1869 , where the Court speaks of "an indestructible Union composed of indestructible States."

While the great work of Chief Justice Marshall is recognized throughout the world, yet it is a source of pride and pleasure to every American to know that this great Court has at all times been composed of men who were noted for their ability, character and integrity, and the high reputation of the presiding officers of that Court has at all times been maintained, the distinguished American who now presides over that tribunal being in every way a worthy successor of his illustrious predecessors.

While Marshall was Chief Justice, eleven hundred and six cases were decided by the Supreme Court, of which he wrote the opinions in five hundred and nineteen. Out of the sixty-two cases involving constitutional questions which the Court decided while he was Chief Justice, thirty-six of the opinions were written by him. These figures may give some idea of the extent,

${ }^{33} \mathrm{McC}$ ulloch v. Maryland, 4 Wheaton, 4 ro.

847 Wallace, p. 700. 
but not of the importance of this great man's public services. The extent to which he dominated that Court throughout his long term of service may be shown by the fact that in only eight cases did he file dissenting opinions. ${ }^{35}$

In the five years from 1875 to 1880 , the Supreme Court heard and decided nineteen hundred and fifty-five cases; and at the beginning of 1888 there were twenty-five hundred and seventy-one cases pending on its docket. Since then, its burdens have been relieved by the labors of nine Circuit Courts of Appeals, but still the Supreme Court of the United States is one of the hardest worked Courts in the world.

In the sessions of that great tribunal, quietness, solemnity, dignity and rapidity characterize its proceedings in which respects, as indeed in all others, it is a model for the courts of all the world.

The Supreme Court, as the capstone of the Federal Judiciary, has well earned its title of "Bulwark of the Constitution," in repelling attacks-sometimes open, sometimes insidious-upon that venerable instrument, that Ark of the Nation's Covenant. In doing this, it has defended States Rights from invasion, as vigorously and as effectively as it has overthrown assaults upon the Federal prerogatives. It has indeed proven itself to be the "balance wheel of the Republic."

In the earlier days of our National life, when the newly formed Federal Government was surrounded by powerful states, like an infant King surrounded by fierce, jealous and turbulent barons, its strong, faithful and efficient guardian was the Supreme Court. But, when at the close of the Civil War, the Federal power was unduly exalted, and many would have trampled upon the reserved rights of the states, this same great tribunal interposed its powerful shield for the protection of the real rights of the states, saying as it did in Texas $\nu$. Whitc:

"The preservation of the States and the maintenance of their government are as much within the design and care of the Constitution, as the preservation and the maintenance of the National Government." 36

And, when, even in the midst of Civil War, ill-advised men, flushed with recent victory and intoxicated with power,

ss Political Science Asso'n of University of Michigan, Constitutional History of U.S. as Seen in the Development of Am. Law-a course of lectures; The Federal Supreme Court, by Judge T. M. Cooley:

36 Texas $v$. White, 7 Wallace, 725. 
sought to stretch forth the mighty hand of the Federal Government to illegally seize the property of a private individual, even though he were one of the avowed adversaries of that very Government, the Supreme Court, in the great case of United States $v$. Lee, decided in 1882 , interposed its protecting aegis, proclaiming the fact that America is the land of Law and not of Violence, and that not even the greatest government on earth can override the constitutional rights of a free American citizen.

In the course of the masterly opinion of the Court in that case, Mr. Justice Miller (esteemed by many to rank in ability next to the great Marshall himself), discussing the Constitutional provisions for the protection of the individual, said:

"These provisions for the security of the rights of the citizen stand in the Constitution in the same connection and upon the same ground, as they regard his liberty and his property, and it cannot be denied that both were intended to be enforced by the Judiciary." 37

Further, it was said that no kingly principle can limit the operation of the constitutional guaranties; that no man in this country is so high that he is above the law; that no officer of the law may set that law at defiance with impunity; that all the officers of the government, from the highest to the lowest, are creatures of the law, and are bound to obey it-a sentiment, let me add, worthy to be written in letters of gold, and placed in every American home!

Thus we have seen the great head of the Federal Judiciary Department in Marbury v. Madison, ${ }^{38}$ declining to permit its own powers to be unduly enlarged-in McCulloch $v$. Maryland ${ }^{89}$ repelling an attack upon the powers of a co-ordinate branch of the Government-in U.S. v. Peters, ${ }^{40}$ and Martin v. Hunter's Lessec, ${ }^{41}$ defending the Federal Government from attacks by the States-in Texas $\%$. White, ${ }^{42}$ repelling invasion of State's Rights by the Federal Government-and in $U . S . v . L e c,{ }^{43}$ protecting individuals from oppression by the Government. In the light

\footnotetext{
${ }^{37}$ U. S. v. Lee, 106 U. S., 220.

${ }^{88}$ I Cranch, 137.

${ }^{39} 4$ Wheaton, 316.

${ }^{10} 5$ Cranch, II5.

11 I Wheaton, 304.

127 Wallace, 700.

43106 U. S., 196.
} 
of such a record, we can truly say that the glory of the American Republic is its Judiciary!

Thus far, I have spoken chiefly of the Federal Judiciary. I would not, however, be understood as wanting in appreciation of the splendid contributions to our jurisprudence, and to the maintenance of the Constitution, by State Judges. The names of Taylor, Ruffin, Pearson, Gaston, Bynum, Reed, Pendleton, Tucker, Staples, Kent, Shaw, Walworth, Gibson, Cooley, and many others who have adorned the Bench of their respective states, will ever be venerated and held in grateful rememberance. Indeed, the history of American Law could not well be written without referring to the work of those eminent jurists.

It is a great mistake to suppose that the duty of expounding the Constitution has been devolved upon the Federal Courts alone. From the organization of the Government, that duty has been shared by the courts of the several states, and in many other matters these courts have exercised, under the law, a concurrent jurisdiction with the courts of the Union.

And here it is appropriate to say that as the judges are recruited from the Bar, whatever honor or renown the Judiciary has won, belongs to the legal profession. The most celebrated judgments that have ever been rendered from the Bench were rendered after able and helpful arguments from the Bar. Think of the invaluable contributions to our jurisprudence in the forensic arguments of Hamilton, Webster, and many other brilliant ornaments of the Bar, whose names are familiar to us all!

The Judge, if such a one there be, who imagines that he has no need of the aid of counsel, is to be pitied, as are the unfortunate litigants before him, or rather, I should say, the unfortunate victims of his stupidity and conceit.

To say, moreover, in this connection, that not only has the American Bar won imperishable fame in the Forum and in the Senate, but that in every great movement in our history, which has redounded to the public good and the public honor, the leaders have nearly always been lawyers, would be but to affirm the well-known facts of history which no one can refute.

"Justice," said Mr. Webster, "is the great interest of man on earth; it is the ligament which holds civilized beings and civilized nations together. Wherever her temple stands, and 
so long as it is duly honored, there is a foundation for social security, general happiness and the improvement and progress of our race." 44

If we are to avoid anarchy or civil war, the right to authoritatively construe the Constitution and settle all conflicts with it, must be lodged in some department of the Government. With this tremendous, and therefore, delicate and dangerous, power, no department could be so wisely or so safely trusted as the Judiciary.

I say "wisely," not because judges have any more wisdom than other men, but because the nature of their calling withdraws them from the active affairs of life, the passions generated by which so often becloud or overthrow men's judgment; because long years of considering and deciding controversies makes them more dispassionate, clear-minded and discriminating than they would otherwise be; because the machinery of a judicial tribunal, insuring a full, quiet hearing for both sides and ample time for calm consideration, tends, as far as human agencies can contribute, to insure fair, just and wise decisions; and because the right of appeal from one court to another, which exists in practically all important cases, insures cooling time, reflection and the checking of the decision's soundness by the independent judgment of a new set of men.

I say the Judiciary is the "safest" department of Government to which this great power can be entrusted, not because judges are better or more trustworthy than other men, but because, in the nature of things, the Judiciary Department is powerless to usurp the powers of either the Legislative or Executive branches.

In the language of Alexander Hamilton, the Judiciary "may be truly said to have neither force nor will, but merely judicial judgment and must ultimately depend upon the aid of the Executive arm, for the efficacious exercise even of this faculty." 15

Or, as Professor Willoughby has so well put it:

"With no executive force at its back, and without means of extending its influence either by patronage or command of the public revenues, it relies for the execution of its decrees, upon face).

* Webster's Address on Mr. Justice Story, 3 Story's Rep. VII (Pre-

15 Federalist, p. 483 . 
the legal spirit and reverence for law of the people, and upon their confidence in its justice and their faith in its wisdom." "46

The judge, then, who, by his life, would betray this confidence, or by his unworthy deeds pollute the temple of justice, or destroy the reverence of the People for their laws, let him be Anathema, for, indeed, as Chief Justice Marshall said: "the greatest scourge an angry Heaven ever inflicted upon an ungrateful and sinning people, is an ignorant, a corrupt or a dependent Judiciary." 47

It is a difficult task to undertake to define the relation which the Federal courts sustain to those courts whose duty it is to enforce the laws enacted by the Legislatures of the several states, and lack of space forbids that I should undertake anything like an elaborate discussion of this phase of the question. However, if the Federal Statutes are construed in the spirit in which they are written, and the powers of the Federal courts exercised with due regard to the comity which exists between the Federal and State courts, there can and should be no conflict between these courts.

In discussing this question as to the extent of the power of the State to control the procedure of its Courts, Justice Brewer, in the case of Brown v. New Jersey, 175 U. S., p. I72, says: "The State has full control over the procedure in its courts, both civil and criminal cases, subject only to the qualification that such procedure must not work a denial of fundamental rights or conflict with specific and applicable provisions of the Federal Constitution."

If the law is enforced in accordance with these rules, we have two independent jurisdictions operating in the same territory, performing functions of the highest importance to the people, and at the same time administering laws that are essential to the peace and good order of our country without producing the slightest friction. These systems of jurisprudence are in perfect harmony with the theory of our government and afford a striking illustration of the stability of our institutions.

That there should be any question about the propriety of a non-resident seeking relief in a Federal Court in a case where

16 Supreme Court of U. S., p. 102.

${ }^{17}$ Debates of Va. Convention, 1829, p. 6rg. 
it is sought to cleprive such party of his property in violation of the Constitution of the United States, is amazing, and clearly indicates either a misconception of the law or a disposition to ignore the plain provisions of the Constitution under which we live and by which the State as well as the Federal courts are governed in the administration of the law.

The framers of the Constitution, with a prophetic vision, foresaw the wonderful growth and development of this country, and in anticipation of such growth and development wisely provided in the Constitution for the establishment of Federal tribunals with a view of enabling citizens to enforce in such tribunals the rights to which they are entitled in their intercourse with their fellow men in the large commercial transactions that have grown up as a part of our development as a Nation. These tribunals have been resorted to for that purpose without interruption ever since the establishment of the Fecleral Judiciary and until recently no one has seriously questioned the propriety and wisdom of such procedure.

However, within the past two years some have sought to create the impression that the institution of a suit in a Federal Court by a non-resident for the purpose of enforcing a right guaranteed under the Constitution is in the nature of an invasion of State's Rights. Much has been said in regard to state sovereignty. Newspapers and state officials have undertaken in some instances to determine these questions by methods unknown to judicial procedure, and if such policy had prevailed, it would have resulted in the demoralization of public and private business and would have been in utter disregard of the rights of individuals guaranteed by the Constitution of the United States.

It cannot be successfully asserted that there is an interference with State's Rights so long as the courts of the United States do no more than exercise the judicial power conferred upon such courts by Congress in pursuance of the Constitution. In the case of Smythe v. Ames, I69 U. S., 466, the Court, in referring to the duties of the Federal Court, among other things said:

"The duty rests upon all courts, Federal and State, when their jurisdiction is properly invoked, to see to it that no rights secured by the supreme law of the land is impaired or destroyed by legislation. This function and duty of the Judiciary distinguishes the American system from all other systems of government. The perpetuity of our institutions and the liberty which 
is enjoyed under them depend, in no small degree, upon the power given the Judiciary to declare null and void all legislation that is clearly repugnant to the supreme law of the land."

It is inconceivable that a Circuit Court of the United States should be powerless to afford a remedy to one who seeks to assert a right which is guaranteed by the Constitution of the United States. The Eleventh Amendment, as well as the end to be obtained by the adoption of the same, shows conclusively that those who were responsible for its adoption never dreamed that it could be used to deprive an American citizen of a substantial right conferred upon him by the Constitution of the United States. This amendment being a part of the Constitution, must be construed so as to give full force and effect to each and every provision of the instrument of which it forms a part. Any other construction would be to practically nullify that clause of the Constitution which provides that no State shall pass any laws impairing the obligation of contracts, as well as the Fourteenth Amendment which, among other things, provides that "no State shall make or enforce any law which will abridge the privileges or immunities of citizens of the United States, nor shall any State deprive any person of life, liberty or property without due process of law; nor deny to any person within its jurisdiction the equal protection of the laws."

Strange as it may seem, many of the individuals who profess to favor states' rights are insistent that Congress should legislate so as to regulate the control or management and operation of all corporations whose business is interstate. They also advocate the passage of a child labor law by Congress and are strong supporters of the employers' liability law which was passed by the last Congress. Thus we find that those who now advocate states' rights are in favor of principles that are antagonistic to the views entertained by those who advocated states' rights in the days of Calhoun.

The theory upon which our government was founded is that the Constitution of the United States is supreme and controlling in all matters. It is the supreme law of the land which should be obeyed until the People deem it expedient to modify the same. Every official, state or federal, is required, before entering upon the discharge of the duties of his office, to take an oath to support and maintain the Constitution of the United States and the laws made in pursuance thereof, and the state official who 
takes this oath among other things is required to state that he will support the Constitution and laws of the State not inconsistent with the Constitution and laws of the United States. Therefore, it is as much the duty of the state official to support the courts of the United States in the enforcement of their decrees in regard to matters over which they have jurisdiction, as it is the duty of the Judges of such courts to enforce the law in accordance with the provisions of the Constitution of the United States. To hold that a State, through its Legislature, has the power to enact laws in conflict with the Constitution of the United States by which an individual is to be deprived of either his life, liberty or property, would result in chaos and confusion and defeat the very purpose of those who framed the Constitution in the first instance.

When we come to consider the provisions of the Constitution to which I have referred, we can fully appreciate the wisdom of the framers of that instrument in providing for the establishment of tribunals in which the rights thus guaranteed may be asserted. The Federal courts are in no sense of the word foreign tribunals. They are presided over by Judges selected from among the people of the territory wherein the courts are established, and the jurors are drawn by a non-partisan jury commission from the citizenship of such territory, and every official of the court is a citizen of such territory, and ample means are provided by which litigants may carry their cases from such courts to a court of appeals, and in some instances directly to the Supreme Court, thus affording every opportunity and facility to the citizen that could possibly be afforded in any state court.

Strange to say, there are those who at this day and time insist that the courts have no power to declare an act of the Legislative branch invalid when it is in conflict with the National or State Constitution, and in many instances unwarranted attacks are made upon the Supreme Court of the United States and the Supreme Courts of the States as well as the other Courts of the Nation and States.

The individual who insists that the Courts have no power to declare an act of the National or State Legislature invalid proclaims a doctrine no less dangerous to the public welfare than the conduct of him who by corrupt means seeks to pollute the fountain of justice so as to prevent a fair and impartial con- 
sideration of questions which may be presented to the courts for consideration.

The Judges of this country, with rarest exceptions, have been exempt from criticism calculated to affect their integrity. This is a splendid tribute to the wisdom and foresight of the framers of the Constitution, and while it is a guarantee of the stability of our institutions, at the same time it reflects great credit upon the character of the American people.

To adopt the theory of those who profess to believe that the courts are without authority to declare a legislative act unconstitutional, would be to reverse the uniform policy of this government from its foundation until this good hour. It would be the accomplishment of that which was declared otherwise when the Constitution was adopted, and which has been finally and forever settled by the highest courts, both State and National.

There is a growing tendency on the part of many to incline to theories that are wholly inconsistent with our distinctive form of government, and while at present they are making but little headway, it should be constantly borne in mind that "eternal vigilance is the price of liberty." It might with equal propriety be said that the perpetuity of our institutions depends upon the vigilance of those who believe in the doctrines enunciated by Washington, Hamilton, Madison, Jefferson, Chief Justice Marshall, and the other patriots to whose wisdom and courage we are indebted for the splendid heritage which we now enjoy.

Under our system of government a citizen may lie down at night and rest undisturbed as to the safety of his life and property, and this ideal condition is due to the fact that the strong arm of the law prevails and is supreme on every inch of soil beneath the Stars and Stripes. This condition was made possible as a result of the fair and impartial administration of justice by a Judiciary whose sole ambition was to enforce the law in accordance with the written Constitution drafted by those who sacrificed their all in order that their descendants might be exempt from the acts of tyranny and injustice which inspired them to take the initiative in a movement the like of which in magnitude and importance had never been undertaken by any people on the face of the earth.

I firmly believe that an overwhelming majority of the American people fully appreciate the strength of our Government as 
now constituted, as well as the many blessings that flow therefrom, and while we are occasionally confronted by the spasmodic efforts of those who know not what they do, and whose counsel, if heeded, would disrupt our Government, nevertheless I have an abiding faith in the American people, and I cannot believe that the time will ever come when a government of the People, for the People and by the People shall perish from the face of the earth.

\section{J. C. Pritchard.}

